\title{
Effect of an Organophosphorus Pesticide on Exposure to the Indian Tiger Prawn, Penaeus Monodon
}

\author{
Fiona Paulose ${ }^{1}$, Sherly Williams $\mathbf{E}^{2}$ \\ P.G and Research Department of Zoology, Fatima Mata National College (Autonomous), Kollam 691011, Kerala, India
}

\begin{abstract}
The present study evaluates the effects of an organophosphorus pesticide (Nuvacron), on the tolerance level, biochemical composition of muscle, total haemocyte count and differential count of the post larval stages of the estuarine prawn, Penaeus monodon. Commercial grade pesticide of Nuvacron $36 \%$ by Hindustan Ciba Geigy LTD (India) were procured from an Agrochemical Store at Kollam, Kerala, India. Live specimens of 12 days old post larvae of P.monodon, selected for the study were collected from Matsyafed Hatchery Centre, Thirumullavaram, Kollam, maintained in the laboratory and acclimatized for about 2 weeks before commencement of the experiment in glass troughs of 2 liter capacity each consisting of 10 prawns. Survival and mortality of the prawn was observed for a period of 96 hours. It is evident from the present study that the insecticide was found to be sensitive to P.monodon and the larval stages cannot withstand higher concentration of it. The $L C_{50}$ was found to be $0.0000032 \%$. In the present study the biochemical constituents and the differential haemocyte count showed decrement tendency with the increase in pesticide concentration. Therefore the study will pave the attention for toxicity of Nuvacron and the increasing exposure risk of aquatic flora and fauna to it.
\end{abstract}

Keywords: Penaeus monodon, Nuvacron, Toxicity test, Total haemocyte count (THC)

\section{Introduction}

The widespread application of synthetic pesticides over the past 50 years has led to their extensive occurrence in air, soil and water worldwide. Such an occurrence of pesticides has the potential to exert adverse effects in humans and wildlife. Most insecticides ultimately find their way in to rivers, lakes and ponds [1]-[7] and have been found to be highly toxic to non-target organisms that inhabit natural environments close to agricultural fields. In the past few decades the use of organophosphorus pesticides has largely replaced organochlorins compounds for the agricultural applications. Organophosphorus pesticides always pose acute toxicity but not chronic toxicity on organisms because of their quick degradation [8].Responses to organophosphorus insecticides by aquatic organisms are broad ranged depending on the compound, exposure time, water quality, organism, sex, age and the species [9]-[10].Some organophosphorus pesticides are highly soluble in water and can therefore easily contaminate aquatic ecosystems, thereby increasing the exposure risk of aquatic flora and fauna including crustaceans and other aquatic organisms and may contribute to long term effects in the environment.

In recent years, a variety of shrimp culture methods have been well developed. However information on the toxicity of organophosphorus pesticides on P.monodon is limited. Therefore an attempt has been made to evaluate the toxicity of Nuvacron on the biochemical and haemolymph composition of the marine shrimp, P.monodon.

\section{Literature Survey}

One of the objectives of lethal toxicity test is to enable prediction of the concentration of a pollutant as accurately as possible, that will not harm the ecosystem and biota under study. The use of application factors (AF) applied to acute toxicity tests in water quality criteria has been recognized as a temporary solution to the problem of pollution by toxicants [11]. These factors vary from 0.9 to 0.0001 . 'Safe Concentration' which presumably has no sub lethal chronic effects is derived as a product of the $\mathrm{LC}_{50}$ and the application factor. EPA recommends safe concentration derived by applying an $\mathrm{AF}$ of 0.001 to the 96 hour $\mathrm{LC}_{50}$ value of the toxicant.

$\mathrm{LC}_{50}$ values for larval and juvenile stages of prawn was $0.4 \mu \mathrm{g} / 1$ and $.08 \mu \mathrm{g} / 1$ reported by Wen-Liang and Hung-Hung [12]. The test organism under pesticidal stress can enhance proteolytic activity as a consequence of increased metabolic demand [13]; can damage the midgut gland of P.monodon post larval stages [14]. Someone has recorded that the fall of glycogen content in freshwater prawn Macrobranchiumkistensiswhen exposed to TDTL chemical [15]. The percentage decrease of glycogen in muscle is more; it may be due to over exertion activity of muscle under pesticidal stress.

A similar depletion in the tissue protein content in different tissues of crustaceans on exposure to various pesticides has been documented in the white prawn, F.indicus on exposure to sublethal levels of phosphamidon and methyl parathion by [16] ; in the fresh water field crab, Paratelphusahydrodromous following exposure to malathion by [17]. Proteins are the building blocks of the animal's body, and it is the most fundamental biochemical substance to maintain the blood glucose and energy source during the stress period. Proteins play a major role in the interaction process of the cellular medium in the organisms [18]. The protein reduction might be due to the impaired or low protein synthesis under the toxic stress condition and enhancement of proteolytic activity in the organisms. A marked decrease in the concentration of the tissue protein in the fresh water prawn M.malcolmsonii[19] on exposure to ensosulfan have been reported. The tissue of the estuarine 


\section{International Journal of Science and Research (IJSR) \\ ISSN (Online): 2319-7064}

Index Copernicus Value (2013): 6.14 | Impact Factor (2014): 5.611

mussel Sunettascripta shows significant decrease in the percentage of lipid content [20]. The organophosphorus pesticides can reduce the composition of carbohydrate, lipid and protein content in all tissues and the depletion was observed to be concentration dependent [21].

The results of total haemocyte composition and DHC reduction soon after the exposure to pesticide in the present study was supported by Charles Taylor [22],[23]-[24]. Effect of extrinsic and intrinsic factors on the haemocyte profile of the prawn showed increased THC during the first 6 hours [25]. The test organism when exposed to experimental sub lethal concentration, an initial decrease in the haemocyte count was noticed and the sub lethal infection gradually induced higher haemocyte count towards the later period of the experiment [26].THC and DHC of the present study also showed the decreased haemocyte count immediately after exposure to test concentration. The THC and DHC gradually increase with an increase in time and concentration.

Protein is one of the important biochemical components and plays an important role in metabolic pathways and biochemical reactions. Under extreme stress conditions, the energy will be supplied by the protein for metabolic pathways and biochemical reaction. Therefore an assessment of the total protein content in different tissues could be used as a diagnostic tool for determining the physiological status of an organism [27].

Generally, in invertebrates, depletion of glycogen reserves has been attributed to increasing energy demand associated with toxic stress caused by pollutants [28]. Reddy and Rao [29-30] reported that the hepatic glycogen content decreased when penaeid prawn (Metapenaeusmonoceros) were exposed to $10,20,30$, and $40 \mathrm{mg} / \mathrm{L}$ methyl parathion for 5 days and hepatic glycogen was more rapidly utilized in shrimp exposed tosublethal concentrations of methyl parathion than that in the muscle. Previousstudies reported that whiteleg shrimp exposed to $0.19 \mathrm{mg} / \mathrm{L}$ lindane, $0.12 \mathrm{mg} / \mathrm{L}$ chlorpyrifos, $0.27 \mathrm{mg} / \mathrm{L}$ chlordane, and $0.13 \mathrm{mg} / \mathrm{L}$ DDT had decreased glycogen synthesis [31]. These authors explained that the decrease in the glycogen content might be due to decreased glycogen synthetase activity and increased glycogen utilization.

\section{Problem Definition}

Insecticides are toxicants which can induce changes in the behavior, physiology, histology, immunology, biochemistry and life in total of non-target aquatic organisms. One of the important aspects, which lethal toxicity tests often overlook, is the fact that though animals succumb to toxic substances after exposure to specific concentration for specific period of time, the actual damage to their physiology is initiated at a much earlier stage by even meager concentration of the substance. In order to evaluate the actual potency of a substance causing deleterious effects in an organism, it is necessary to conduct sublethal chronic exposure studies.

\section{Materials and methods}

\subsection{Chemical}

Commercial grade pesticide of Nuvacron $36 \%$ (monocrotophos-Chemical name: dimethyl (E)-1-methyl-2(methylcarbamoyl) vinyl phosphate) manufactured by Hindustan Ciba Geigy LTD(India) were procured from an Agrochemical Store at Kollam, Kerala, India.

\subsection{Test organism}

Live specimens of 12 days old post larvae of P.monodon, selected for the study were collected from Matsyafed Hatchery Centre, Thirumullavaram, Kollam and maintained in the laboratory. Toxicity tests were performed on the postlarval stage. The tests were conducted in glass troughs of 2 liter capacity each consisting of 10 prawns. Survival and mortality of the prawn was observed for a period of 96 hours. The test prawn was brought to the laboratory and kept in glass aquaria $\left(3^{\prime} \times 2^{\prime} \times 1^{\prime}\right)$ holding sea water at $29 \pm 1^{\circ} \mathrm{C}$ under well aeration. Prawns were acclimatized for about two weeks before commencement of the experiment. The prawns were fed with egg yolk and artemia. The excretory wastes were siphoned out daily.

\subsection{Static Acute Toxicity Test}

Nuvacron pesticide taken for the present study was available with $36 \%$ concentration. The present study was carried out with absolute concentration. To convert $36 \%$ concentration to $10 \%$ working stock solution, $14 \mathrm{ml}$ of pesticide was dissolved in $36 \mathrm{ml}$ of distilled water.i.e. $50 \mathrm{ml}$ solution contains $5 \mathrm{ml}$ of pure pesticide. This means that $1 \mathrm{ml}$ of solution contains $0.1 \mathrm{ml}$ of pure pesticide. From this wide ranges of concentrations are made using distilled water.Based on the range finding tests, five desired concentrations of the pesticide $0.000002 \%$, $0.000003 \%, 0.000004 \%, \quad 0.000005 \%, \quad 0.000006 \%$ of Nuvacron were selected and 10 nauplii per well were maintained in the test solution. The nauplii were not fed during the exposure period. Animals were recorded as being dead if no discernible movements were observed during 10 seconds of observation period under a dissection microscope. The mortality of the post larvae were checked after specific period of exposure $(96 \mathrm{hrs})$. At the end of each test, the number of dead animals were counted and discarded.

The biochemical composition of muscle and haemolymph composition were studied in two sublethal concentrations using geometric progression concentration method [32]. A control was run parralelly. Sub lethal concentrations used for the present study were $0.000002 \%$ and $0.000001 \%$. The biochemical and haemolymph composition were analyzed before and after the exposure of prawn to the desired sublethal concentration for a period of 21 days. The experiments were conducted in replicate, along with that the control and average values were also taken. Glycogen estimation was followed by Anthrone method [33], Protein by Folinciocaltenmethod [34] and Lipid by Folch method [35]. Total haemocyte count and differential heamocyte count was enumerated by Neubauer method[36]. Data on 


\section{International Journal of Science and Research (IJSR) \\ ISSN (Online): 2319-7064}

Index Copernicus Value (2013): 6.14 | Impact Factor (2014): 5.611

percentage mortality were used to calculate the $96 \mathrm{hr} \mathrm{LC}_{50}$ by probit analysis [37].

\section{Results and Discussion}

\subsection{Toxicity test- $\mathrm{LC}_{50}$}

Exposure of post larval stages of P.monodon to various concentrations of monocrotophos pesticide for a period of 96 hours revealed obvious differences in the responses to varying concentrations of test solution. Lethal concentration $\left(\mathrm{LC}_{50}\right)$ for post larval stage was found to be $0.0000032 \%$ (absolute). Graphical representation of $\mathrm{LC}_{50}$ is shown in Fig.1.The percentage mortality of P.monodon on experiments with varying concentrations of Nuvacron is shown in table 1.

Table 1: $96 \mathrm{hr}$ Percentage mortality of post larvae of Penaeus monodon on exposure to varying Concentrations

\begin{tabular}{|c|c|}
\hline Concentration (\%) & Mortality (\%) \\
\hline 0.000002 & 30 \\
\hline 0.000003 & 44 \\
\hline 0.000004 & 60 \\
\hline 0.000005 & 74 \\
\hline 0.000006 & 90 \\
\hline
\end{tabular}

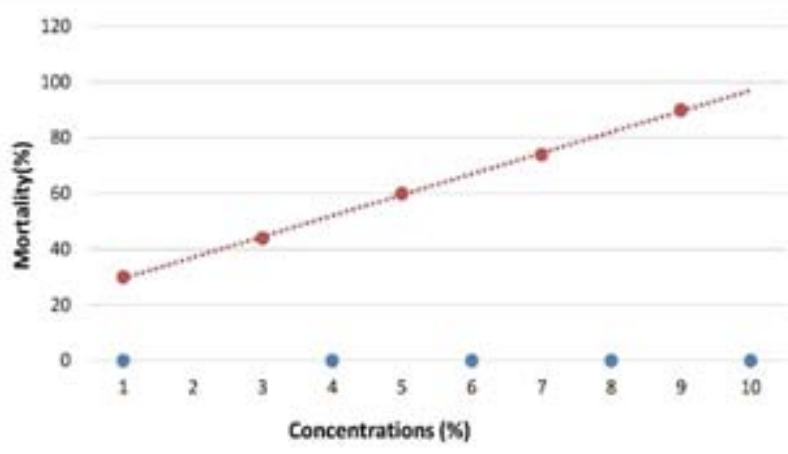

Figure1: Graphical representation of $96 \mathrm{hr} \mathrm{LC} \mathrm{LC}_{50}$ (Probit Method)

\subsection{Biochemical Changes}

The initial muscle biochemical components (protein, lipid and glycogen) were measured prior to acclimatization at normal environmental conditionsarepresented in table 2 . Fluctuations of protein in the muscle of prawn after exposure of 21 days to different concentrations of the pesticide, nuvacron is also shown in table 2. During the period of exposure the muscle protein content for P.monodon at control, $0.000001 \%, 0.000002 \%$ of nuvacron were found to be $12.5 \%, 8.7 \%$ and $3.3 \%$ respectively. Protein content indicated decline with the increase in concentration of pesticide. The values of glycogen content of the muscle of prawn after 21 days of exposure to varying concentrations were depicted in table 2. Initial glycogen content of muscle was $43.86 \%$. After the exposure period it was found to be $24.33 \mathrm{mg} \%, 10.77 \%, 3.66 \%$ for control, $0.000002 \%$ and $0.000001 \%$ respectively. Higher medium marked low glycogen content than that of lower medium. An initial value of lipid composition prior to the experiment was $38.02 \%$. The values after exposure period were $16.87 \mathrm{mg} \%$, $9.04 \mathrm{mg} \%$ and $12.84 \mathrm{mg} \%$ for control, $0.000002 \%$ and
$0.000001 \%$ respectively. The decrement in the total lipid level may be due to the increased activity levels of lipase, the enzyme responsible for the breakdown of lipid in to the free fatty acids and glycerol. Lipids constitute the rich alternate energy reserves whose calorific value is twice that of an equivalent weight of carbohydrate and proteins and the mobilization of lipid reserves may be due to the imposition of high energy demands to counter the toxic stress. The values of the biochemical components in the control were higher than that of the values after exposure to the pesticide.

Table 2: Biochemical composition of muscle protein, lipid and glycogen of Penaeus monodon before and after exposure period of 21 days

\begin{tabular}{|c|c|c|c|c|}
\hline Biochemical & \multirow{2}{*}{$\begin{array}{c}\text { Before } \\
\text { component } \\
\text { experiment }\end{array}$} & \multicolumn{3}{|c|}{$\begin{array}{c}\text { After exposure pesticide } \\
\text { concentration(\%)(Final) }\end{array}$} \\
\cline { 3 - 5 } (initial) & Control & 0.000001 & 0.000002 \\
\hline Protein & 32.15 & 12.5 & 8.75 & 3.33 \\
\hline Glycogen & 43.86 & 24.23 & 10.77 & 3.66 \\
\hline Lipid & 38.02 & 16.87 & 9.04 & 12.84 \\
\hline
\end{tabular}

\subsection{Total haemocyte count (THC)}

The cellular immune mechanism is functional in animals, active phagocytic cells ingesting and eliminating invading particles. P.monodon possesses three different types of blood cells, non-granular hyaline cells,semigranular and large granular heamocytes. In healthy post larvae of P.monodon (12 days old) under the control experiment on the first day, THC was 95000 cells $/ \mathrm{mm}^{3}\left(9.5 \times 10^{4}\right)$ and on the $21^{\text {st }}$ day of the experiment, it was $1,00000\left(10^{5}\right)$ cells $/ \mathrm{mm}^{3}$.For those individuals maintained in the experimental safe concentration of pesticide i.e., 0.000001 $\%\left(1 \times 10^{6}\right)$ and $0.000002 \%\left(2 \times 10^{6}\right)$ showed a sudden decrease in the THC during the initial day and increase in THC towards the later phase of the experiment (Table 3). For the concentration of $0.000001 \%$, the THC for the first day was $9000 \mathrm{cell} / \mathrm{mm}^{3}\left(9 \times 10^{3}\right)$ and for the $21^{\text {st }}$ day it was 80,000 cell $/ \mathrm{mm}^{3}\left(8 \times 10^{4}\right)$. For the concentration of $0.000002 \%$, the THC for the first day was 7000 cells $/ \mathrm{mm}^{3}$ $\left(7 \times 10^{3}\right)$ and for the $21^{\text {st }}$ day it was 98,000 cells $/ \mathrm{mm}^{3}(9.8 \times$ $10^{4}$ ) (Table-3, Figure-4)

Table 3: Total haemocyte count of Penaeus monodon on exposure to experimental concentration of pesticide

\begin{tabular}{|c|c|c|}
\hline \multirow{2}{*}{$\begin{array}{c}\text { Concentration } \\
(\%)\end{array}$} & After one day(cell/mm3) & After 21 days cell $/ \mathrm{mm} 3)$ \\
\hline Control & $9.5 \times 10^{4}$ & 105 \\
\hline 0.000001 & $9 \times 10^{3}$ & $8 \times 10^{4}$ \\
\hline 0.000002 & $7 \times 10^{3}$ & $9.8 \times 10^{4}$ \\
\hline & & \\
\hline \\
1000
\end{tabular}

Figure 4: Total haemocyte count of P.monodon on Experimental concentration of pesticide

\section{Volume 5 Issue 1, January 2016}




\section{International Journal of Science and Research (IJSR) \\ ISSN (Online): 2319-7064}

Index Copernicus Value (2013): 6.14 | Impact Factor (2014): 5.611

\subsection{Differential haemocyte count (DHC)}

DHC of P.monodon after one day and 21 days are presented in table 4 and figure 2 and 3. After one day hyaline cells, semigranular cells and granular cells were found as $80 \%$, $14 \%$ and $6 \%$ respectively in the control whereas percentage of DHC for the experimental concentrations $(0.000001 \%$ and $0.000002 \%$ ) were decreased drastically with the increase in concentration. After 21 days of exposure, all the three types of cells in control experiment showed more or less same values as that of initial value. But the percentages of heamocytes under two safe concentrations were found to be increased than that of the control valuesafter 21 days of exposure.

Table 4: Differential haemocyte count of Penaeus monodon on exposure to experimental concentration

\begin{tabular}{|c|c|c|c|c|c|c|}
\hline $\begin{array}{c}\text { Type of cells } \\
(\%)\end{array}$ & \multicolumn{3}{|c|}{$\begin{array}{c}\text { After one day } \\
\text { Concentration \% }\end{array}$} & \multicolumn{3}{c|}{$\begin{array}{c}\text { After 21 days } \\
\text { Concentration \% }\end{array}$} \\
\hline & Control & $0.00 \%$ & $0.00 \%$ & Control & $0.00 \%$ & $0.00 \%$ \\
\hline HC & 80 & 45 & 30 & 81 & 80 & 82 \\
\hline SGC & 14 & 8 & 3 & 15 & 11 & 12 \\
\hline GC & 6 & 3 & 1 & 4 & 9 & 6 \\
\hline
\end{tabular}

*HC-Hyaline Cells, ${ }^{*}$ SGC- Semi Granular Cells

*GC- Granular Cells

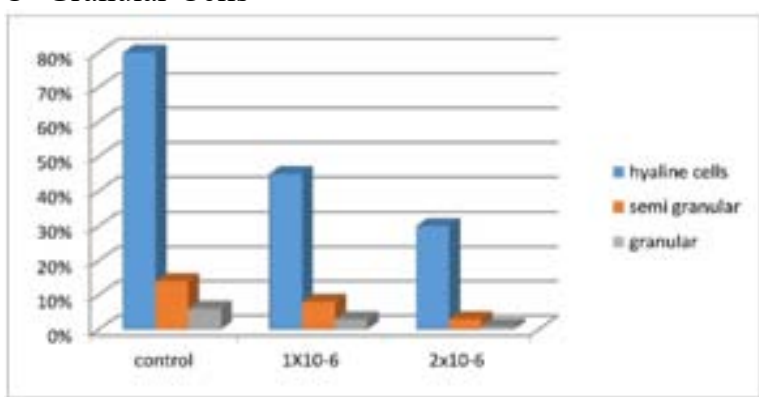

Figure2: Differential haemocyte count of P.monodon on experimental concentration after one day

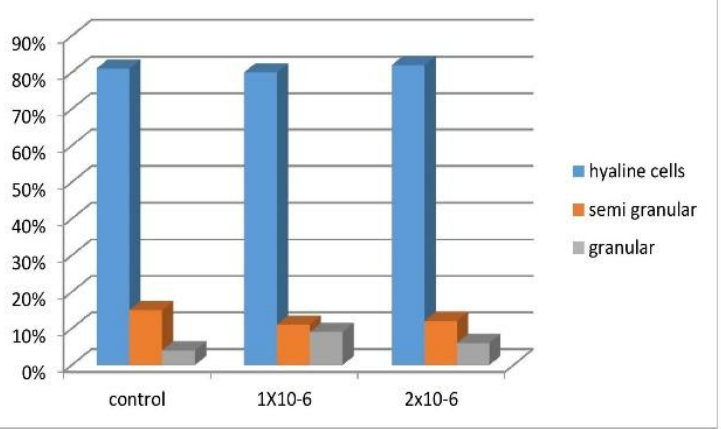

Figure 3: Differential haemocyte count of P.monodon On experimental Concentration after 21 days

\section{Conclusion}

It is expected that the use of pesticides, will continue to increase and eventually becoming an environmental hazard to non-target organisms at different biological scale levels unless proactive measures are taken. Heavy use of pesticides must be reduced drastically and replaced with improved culture techniques. Recent research has provided evidence that current aqua cultural production practices could lead to exposures to various pesticides. However, such chemicals can also impair prawn health and can accumulate inside muscle and, therefore, should be forbidden for sale. Normally, to assess exposure to pesticides, their presence in penaeidshrimp is determined. It is possible that there are elevated residues but no physiological or biological effects because of low bioavailability, this strategy can sometimes lead to conflicting results. The case study, i.e. sublethal exposures of P.monodon to varying concentrations of Nuvacron, showed that P.monodon can be used as an early detection system to assess organophosphorus-based pesticide pollution effects on aquaticecosystems.

\section{Future Scope}

The use of chemicals is a major problem in shrimp aquaculture, with a significant potential to have anegative impact on the environment and human health. Indiscriminate use of highly persistent pesticides in agriculture and public health programmes has resulted in contamination of environment causing hazards to wild and aquatic life. The runoff from agricultural land is one of the main sources of gradual pesticide pollution of aquatic environment. Hence, toxicological studies of the pesticide upon aquatic organisms are very important from the view point of environmental consequences. Influence of pesticides on the biochemical constituents of the species helps in assessing the palatability of the species, which directly affects the consumer's health as the presence of residues of the insecticide and/or of their metabolites in shrimp may have adverse effects on the same.

\section{References}

[1] S. Tarahi Tabrizi. Study of pesticide residues (diazinon, Malathion, metasytoux) in the Tabriz Nahand River, M.Sc.Thesis, Tehran University of Medical Science, Tehran, Iran, pp.88, 2001. (Project Thesis style)

[2] K. Honarpajouh. Study and identification of OP pesticides residues (Azinphosmethyl and Diazinon) in the Mahabad and Siminerood rivers, M.Sc. thesis, Tehran University ofMedical Science. Tehran, Iran, pp. 95, 2003.(Project Thesis style)

[3] F. Bagheri. Study of pesticide residues (Diazinon, Azinphosmethyl) in the rivers of Golestan province (GorganRoud and Gharehsou), M.Sc. thesis, Tehran University of Medical Science.Tehran, Iran, $125 \mathrm{pp}$, 2007.(Project thesis style)

[4] M. Shayeghi, H. Darabi, H. Abtahi, M. Sadeghi, F. Pakbaz, S.R. Golestaneh. Assessment of persistence and residue of diazinon and malathion in three Rivers (Mond,Shahpour and Dalaky) of Bushehr province in 2004-2005 years. Iranian South Med. J., 10: 54-60, 2007.(Journal style)

[5] Vryzas, Z. Vassiliou, G.Alexoudis, C. andE. Papadopoulou-Mourkidou .Spatial and temporal distribution of pesticide residues in surface waters in northeastern Greece.Water Res., 43: 1-10, 2009.(Journal style)

[6] K. Werimo, A.A.Bergwerff, andW. Seinen. Residue levels of organochlorines and organophosphates in water, fish and sediments from Lake Portion. Aquatic Eco. HealthManag., 12: 337-341, 2009.(Journal style)

[7] R.Arjmandi, M. Tavakol, M. Shayeghi. Determination of organophosphorus insecticide residues in the rice paddies .Intl. J. Environ. Sci. Technol., 7: 175-182., 2010. (Journal style) 


\section{International Journal of Science and Research (IJSR) \\ ISSN (Online): 2319-7064}

Index Copernicus Value (2013): 6.14 | Impact Factor (2014): 5.611

[8] J .Ye, M. Zhao, J. Liu W. Liu. Enantioselectivity in environmental risk assessment of modern chiral pesticides. Environ. Pollut, 158, 2371-2383, 2010. (Journal style)

[9] Silva Filho, M.V., Oliveira, M.M., Salles, J.B., Cunha Bastos, V.L.F., Cassano, V.P.F, Cunha Bastos, J. Methyl-paraoxon comparative inhibition kinetics for acetyl cholinesterase from brain ofneotropical fishes, Toxicology letters, 153, pp 247-254,2004.(Journal style)

[10] Narra Madhusudan Reddy, B. Ghousia, K. Rajender, J. V. Rao. Toxic Impact of two organophosphate insecticides on biochemical parameters of a food fish and assessment of recovery response, Toxicology \& industrial health, DOI: 0748233711412423, pp1-10, 2011a. (Journal style)

[11] NAS/NAE. National Academy of Sciences/ National Academy of Engineering: Water qualityCriteria $U \mathrm{~S}$. Government Printing Office, Washington D C. 549 P, 1973.(Book style)

[12] Wen-Liang Chan and Hung-Hung Sung. The toxic effect of phthalate esters On immune responses of giant freshwater prawn via oral treatment. Aquatic Toxicology 74 (2): 160-171, 2005.(Journal style)

[13] P.S. Kharat, B. Laxmi, K.B. Ghoble, Shejule, B.C. Ghoble. Effect of TBTCL on glycogen profile in freshwater prawn Macrobranchiumkistnensis. World Applied Sciences Journal, 7 (12), 1534- 539, 2009. (Journal style)

[14] Gunter Vogt. Monitoring of environmental pollutants such as pesticides in prawn aquaculture by histological diagnosis. Aquaculture 67(1-2): 157-1 64, 1987. (Journal style)

[15]P. S. Kharat, Laxmi B Ghoble, K. B. Shejule, R.S. Kale, B.C. Ghobe. Impact of TBTCI on Total Protein content in fresh water prawn Macrobrachium kistensis. Middle East. J. of scientific Research4 (3):180-1 84, 2009. (Journal style)

[16]S. Reddy, KVR Rao. Methyl parathion induced alterations in the Tissue carbohydrate catabolism of marine prawn, Metapenaeus monoceros. Bull Environ ContamToxicol 47:925-932, 1991. (Journal style)

[17] Singaraja, R. Subramanian and M .A Varadaraj.Sublethal effects of Malathion on the Protein metabolism in the fresh water field crab Paratelphusahydrodromous. J. Ecotoxicol. Environ. Monit. 1: 41-44, 1991. (Journal style)

[18]R.S. Magar, Afsar Shaikh. Biochemical changes in proteins and amino acids in Channa punctatusin responses to sub lethal treatment with the insecticide Malathion, 1(3), 2319-4731, 2012. (Journal style)

[19]P. S. Bhavan, P. Geraldine. Alterations in concentrations of protein, carbohydrate glycogen, free sugar, and lipid in the prawn, Macrobrachium malcomlsonii on exposure to sublethal concentrations of ensosulfan. Pestic. Biochem, Physiol. 58: 89-101, 1997. (Journal style)

[20] S .V. S. Amanulla Hameed, T. A. Nazi Ahamed, D. S .M. Sha. Effect of butylin toxicity on lipid metabolism in an estuarine musselSunettascriptaJ. Exotoxicor. Environ. Monit, 14(3):185-1 90, 2004. (Journal style)

[21]A. Anusha Amati, Cyril Arunkumar, L. F.X. Elizabeth Jayanthi, M. Selvanayagam. Quinalphos induced biochemical anomalies in Cirrhinusmrigala (Ham) $J$. Environ Bio. 17 (2): 121-124, 1996. (Journal style)

[22] Charles Taylor. M.sc Project Thesis from the University of Waikato on the topic "Flow Cytometric Enumeration of the blood cells of Rainbow trout (Onchorhynchusmykiss) and Newzealand freshwater cray fish (Paranephropsplanifrons)" , 2009. (Project Thesis style)

[23] S. Lorenzon, M. Francese, V.J. Smith, E .A. Ferrero. Heavy metals affect the circulating haemocyte number in the shrimp Palaemon elegans. Fish and selfish Immunology 11 (6):459 472, 2001. (Journal style)

[24] S .Agrahari, K. C. Pandey, K. Gopal. Effect of Monocrotophos on Erythropoetic activity and hematological parameters of the fresh water fish Channapunctatus (Bloch) Bull. Of Environmental contamination and Toxicology. 76(4) :607-613, 2006.(Journal style)

[25] Winton Chang and Jian-Chuchen. Effect of intrinsic and extrinsic factors on the haemocyte profile of the prawn, Macrobrachium rosenbergii. Fish and Shell fish Immunology 11 (1): 53-63, 2001. (Journal style)

[26] Cyrille Goarant, Eric Boglio.Changes in haemocyte count in Litopenaeusstyliroshin subjected to sublethal injection and to Vaccination. Journal of the world Agriculture Society 31(1):123-129, 2007. (Journal style)

[27]P .M. D. Prasanth, Arivoli. Biochemical study of freshwater fish Catla catla with reference to mercury chloride. Iran. J. Environ. Health Sci. Eng. 3: 109-116, 2008. (Journal style)

[28] R.L Graney, J.P. Giesy. Effects of long-term exposure to pentachlorophenol on the free amino acid pool and energy reserves of the freshwater amphipod Gammarus pseudolimnaeusBousfield (Crustacean Amphipod). Ecotoxicol Environ Saf 12:233-251, 1986. (Journal style)

[29] S. Reddy, K.V.R Rao. Methyl parathion-induced alterations in the acetyl cholinesterase and phosphatases in a penaeid prawn, Metapenaeusmonoceros. Bull Environ Contam Toxicology 45:350-357, 1990.(Journal style)

[30] M. S Reddy, K .V. R Rao and B. N Murthy. Changes in nitrogen metabolism of penaeid prawnPenaeus indicus, during sublethal phosphamidon and methyl parathion induced stress. Bull. Environ. Contam. Toxicol. 41 :3443, 1991. (Journal style)

[31]J.G Galindo-Reyes, J.A Medina, L.C Villagrana. Physiological and biochemical changes in shrimp larvae (Penaeus vannamei) intoxicated with organochlorine pesticides. Mar Pollut Bull 32:872-875, 1996. (Journal style)

[32] P.Doudoroff, B. G. Anderson, G. E. Burdick, P. S. Galtsoff, W. B. Hard, R. Patrick, E. R. Strong, E. M. Farberg, Vanworm. Bioassay method for the evaluation of acute toxicity of industrial waste for fish. Sewage and Industrial waste 23: 1380-1397, 1951.(Book chapter style)

[33] Sciefteret al., was used to determine the fat body glycogen research. Guilan. Ac. Ir/cjes/papers/203 : 2015-2021, 1950.(Book chapter style)

[34] O. H. Lowry, N. J. Roserrough, A. L. Farr, R. J. Randall. Protein measurement with folin phenol 


\section{International Journal of Science and Research (IJSR) \\ ISSN (Online): 2319-7064}

Index Copernicus Value (2013): 6.14 | Impact Factor (2014): 5.611

reagen.tJ. Biol. Chem. 193 : 265-275, 1951. (Book chapter style)

[35] J.Folch, M. Lees, G. H. Stantely. A simple method for the isolation and purification of total lipid from animal tissue.J.Biol.Chem.226:497-509, 1957. (Journal style)

[36] T.W.Campbell, c.f. Avian Heamotology and cytology, 1995.(Book style)

[37]D.J. Fenny. Probit Analysis. 2nd Ed. Cambridge, London and New York Cambridge University press, 1971. (Book style)

\section{Author Profile}

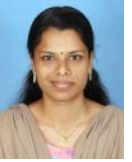

Fiona Paulose received the B.Sc. and M.Sc degrees in Zoology from Kerala University in 2008 and 2010, respectively. Qualified NET IN 2012. Worked as Guest Lecturer in B.J.M Government College Chavara and Fatima Mata National College, Kollam in 2012-2013, 2015 respectively. Currently doing research (Topic: Studies on the Seasonal Variation in Food and Feeding of Oxyuricthys Tentacularis (Valenciennes, 1837).

Dr. Sherly Williams E, Associate Professor, (1999till date), Dept. of Zoology, Fatima Mata National College (Autonomous), Kollam. Academic Qualification: MSc, PhD (Biology of certain intertidal organisms) Areas of teaching specialization: Zoology (Aquatic Biology and Fisheries). Areas of research Specialization: Environmental Sciences, Aquaculture and Fish Biotechnology Completed PhD under guidance: 1 Progress: 7 Membership in academic bodies of University: 1. Life member Marine Biological Association of India 2. Life member Inland Fisheries Society India. 3. Life member National Environmentalist Association. 4. Life member The Indian Science Congress Association. Publication details: International Journal: 17 National Journal: 26 Peer Reviewed: 41 Magazine: 1 